\title{
Direct Identification of Northern Sage-grouse, Centrocercus urophasianus, Nest Predators Using Remote Sensing Cameras
}

\author{
Matthew J. Holloran and Stanley H. ANDERSON
}

Wyoming Cooperative Fish and Wildlife Research Unit, Box 3166 University Station, University of Wyoming, Laramie, Wyoming 82071 USA

Holloran, Matthew J., and Stanley H. Anderson. 2003. Direct identification of Northern Sage-grouse, Centrocercus urophasianus, nest predators using remote sensing cameras. Canadian Field-Naturalist 117(2): 308-310.

The status and apparent decline of Sage-grouse (Centrocercus spp.) has been of increasing concern and lower nesting success could be contributing to population declines. Our objective was to directly identify Sage-grouse nest predators. Following visual confirmation of radio-marked Sage-grouse nest establishment in 1997-1999, we installed automatic 35 $\mathrm{mm}$ cameras controlled by an active infrared monitor. Of 26 nests monitored by cameras, 22 successfully hatched and four were unsuccessful. American Elk (Cervus canadensis), Badger (Taxidea taxus), and Black-billed Magpie (Pica hudsonia) destroyed three of the four unsuccessful nests, and domestic cattle caused abandonment of the fourth. Richardson's (Spermophilus richardsonii) and Thirteen-lined Ground Squirrels (S. tridecemlineatus) were recorded at nests, but were not detected in predation.

Key Words: Centrocercus urophasianus, Sage-grouse, Cervus canadensis, American Elk, ground squirrel, predator.

Northern Sage-grouse (Centrocercus urophasianus) were once abundant throughout Wyoming's sagebrush (Artemisia spp.) habitats (Patterson 1952). Since the 1970s, however, statewide harvest and lek attendance data indicate Sage-grouse numbers have declined (Wyoming Game and Fish Department [WGFD] harvest reports 1976-1993, Cheyenne, Wyoming; Connelly and Braun 1997). A decline in nesting success has been proposed as a factor contributing to the decline in Sage-grouse populations (Heath et al. 1996*).

Many studies have identified predation as the primary factor directly influencing Sage-grouse nesting success (Batterson and Morse 1948*; Autenrieth 1981*; Crawford et al. 1992*; Heath et al. 1997*). Although most ranchers and hunters consider Coyotes (Canis latrans) the primary Sage-grouse predator (Matt Holloran, personal observation), the percentage of bird and eggshell fragments as a whole in Coyote prey base studies ranged from 2 to $<7 \%$ (Johnson and Hansen 1979; Reichel 1991; Heath et al. 1996*), suggesting minimal impact on Sage-grouse. Common Ravens (Corvus corax), Black-billed Magpies, Red Fox (Vulpes vulpes), and Badgers (Taxidea taxus) have been identified as predominant Sage-grouse nest predators (Autenrieth 1981*; Connelly et al. 1991; Heath et al. 1996*). Patterson (1952) reported that $42 \%$ of Sage-grouse nest predation in Wyoming was due to Richardson's and Thirteen-lined ground squirrels (Spermophilus richardsonii, S. tricemlineatus).

Predator identification has usually been indirect, based on sign and eggshell characteristics. Our objective was to identify Sage-grouse nest predators directly in the Bates Creek region of central Wyoming.

\section{Methods}

Thirty-six female Sage-grouse were captured on and near leks from mid-March through April 1997-
1999 on the 31000 ha, high elevation $(2170-2350 \mathrm{~m})$ Bates Creek Grazing Allotment $\left(42^{\circ} 30^{\prime} \mathrm{N}, 106^{\circ} 15^{\prime} \mathrm{W}\right)$ in southeast Natrona County, Wyoming. We used spotlighting and hoop-netting (Giesen et al. 1982; Wakkinen 1990) to capture the grouse. Each hen was fitted with a radio-transmitter package (Advanced Telemetry Systems Inc., Insanti, Minnesota) secured with a PVC-covered wire necklace so the transmitter was on the upper breast. Transmitters weighed $12 \mathrm{~g}$, had a battery life expectancy of 305 days, and were equipped with motion-sensitive sensors. Birds were released at point of capture after processing.

Radio-marked hens were monitored bi-weekly through the pre-laying (April) and nesting (MayJune) periods of 1997-1999 using hand-held receivers and 3-element Yagi antennas. Nest locations of radiomarked hens were determined by circling the bird until visual confirmation was made. One week after visual confirmation of nest establishment, we installed an automatic $35 \mathrm{~mm}$ camera (TM 35-1 ${ }^{\mathrm{TM}}$; Trailmastec, Lenexa, Kansas) triggered by an active infrared monitor (TM 1500 ${ }^{\mathrm{TM}}$; Kucera and Barrett 1993). One camera was placed in a metal ammunition box and concealed in a shrub within $2 \mathrm{~m}$ of each nest. We used two cameras in 14 cases where one camera could not cover all major nest visitation routes. The cameras were aligned to capture the activity within the nest bowl and the infrared beams were positioned across the main escape route(s) between five and $10 \mathrm{~cm}$ above the ground. The infrared monitor was programmed to trigger the camera when the beam was broken for $\geq 0.05$ seconds, the delay between photographs was 6 seconds (minimums for the equipment), and one picture was taken each time the beam was broken. We used 36-exposure film that was replaced every fifth day. Rubber boots were worn, and sage-masking scent (Wildlife Research Center, Inc., Anoka, Minnesota) was used each time 
nests were visited. An additional 12 artificial nests were constructed within randomly determined suitable nesting habitat using either chicken or abandoned Sage-grouse eggs, and monitored until all nests hatched.

\section{Results}

Thirty-three of $36(92 \%)$ radio-marked females initiated nests and had camera(s) installed. Seven hens abandoned, possibly as a direct result of camera installment (discussed in Holloran and Anderson, in review). The seven abandoned nests were monitored and included in the sample of 12 artificial nests. Of the 26 Sage-grouse nests with cameras, 22 successfully hatched (85\%) and four were unsuccessful. An American Elk, Black-billed Magpie, and Badger predated three of the four unsuccessful nests. Repeated disturbance by domestic cattle (the nest was between an upland pasture and a watering site) caused abandonment of the fourth unsuccessful nest. Additionally, elk were recorded at three artificial nests, and appeared to test the eggs; the eggs were cracked, not eaten. In all four elk involved nest loss cases, bull elk were responsible for eating (the actual Sage-grouse nest) or testing the eggs. Cow elk were recorded at two successful Sagegrouse nests and two artificial sets, but did not show interest in the eggs. Ground squirrels were recorded near three separate nests (two successful, one artificial), but none was destroyed. Other animals recorded at nest sites include: Pronghorn (Antilocapra americana), White-footed Mouse (Peromyscus sp.), Whitetailed Jackrabbit (Lepus townsendii), and Least Chipmunk (Eutamias minimus). Additionally, badgers were recorded at two artificial nests, but the eggs were eaten at only one of these nests.

\section{Discussion}

In the four nest loss cases where elk were involved (the predated nest and the three artificial nests), bull elk were responsible for eating or testing the eggs. Cow elk were recorded at both Sage-grouse and artificial nests, but did not show interest in the eggs. Requirement of calcium and phosphorus of bull elk, which contribute to antler development (Ullrey 1982; Grasman and Hellgren 1993), may have had a role in these predation events. Additionally, Kevin Warner (Boise State University, Boise, Idaho, personal communication) observed Mule Deer (Odocoileus hemionus), American Elk, and domestic cows at destroyed artificial songbird nests in Idaho using remote triggered cameras. Red Deer (Cervus elaphus) and domestic sheep on the Shetland island of Foula have been documented eating legs and wings of young Arctic Terns (Sterna paradisaea), presumably to supplement a calcium-deficient diet (Furness 1988). White-tailed Deer (O. virginianus) in Manitoba have been documented eating small birds caught in mist nets, and were suspected in destruction of a Yellow Warbler (Dendroica petechia) nest (Sealy 1994).
Thirteen-lined and Richardson's ground squirrels have been indirectly implicated as important Sagegrouse nest predators in Wyoming (Patterson 1952). We recorded both species at active and artificial nests, but the hens did not flush from their nests and no predation was verified. Although ground squirrels have been conclusively identified as predators of waterfowl nests (Sargeant et al. 1998*), our data suggest they do not destroy substantial numbers of Sage-grouse nests.

The Badger at the artificial nest where the eggs were not eaten failed to detect the nest even though it was within $1 \mathrm{~m}$ of the eggs. We do not believe this would have been the case had a hen been present, and surmise that increased scent associated with incubation may increase the probability of predation by mammalian predators. Dense, tall herbaceous vegetation may provide scent and visual barriers between the nests of ground-nesting birds and predators, and reduce the probability of predation (Bowman and Harris 1980; Redmond et al. 1982). Therefore, nest site selection and incubation strategies that decrease the amount of scent associated with the nests should increase the probability of hatching success. This hypothesis supports the importance of herbaceous screening cover within Sage-grouse nesting habitat (Gregg et al. 1994; DeLong et al. 1995).

Nest success for our camera-monitored birds was $85 \%$, while typical Sage-grouse nest success estimates are between 40 and 60\% (Wakkinen 1990; Connelly et al. 1991; Connelly et al. 1993; Sveum et al. 1998). It is possible that our findings are a function of small sample size (26 nests), the condition of the habitat, or other unknown factors because our results differ from those reported using examination of nests following depredation. Additionally, egg laying and the first third of incubation were not monitored by camera. We suggest that studies of Sage-grouse nesting using photographic techniques be replicated, and we urge caution in interpreting these results without spatial and temporal replication and larger sample sizes.

\section{Acknowledgments}

Our gratitude goes to all land owners who allowed access: Mr. and Mrs. Pete Scott, Mr. and Mrs. Charlie Scott, Mr. and Mrs. Jim Price, Mrs. Anne Miles, Mr. and Mrs. Pete Garrott, and Mr. Ron Heward. Brian Heath (WGFD), Todd McCollum, Kevin Downs, Beau Patterson (WGFD), Mike Choma (WGFD), and George Sonne (BLM) provided information and field assistance. The WGFD provided financial support.

\section{Documents Cited (marked * in text)}

Autenrieth, R. E. 1981. Sage-grouse management in Idaho. Wildlife Bulletin 9. Idaho Department of Fish and Game, Boise, Idaho.

Batterson, W. M., and W. B. Morse. 1948. Oregon Sagegrouse. Oregon Game Commission Fauna Series 1. Portland, Oregon. 
Crawford, J. A., M. A. Gregg, M. S. Drut, and A. K. DeLong. 1992. Habitat use by female Sage-grouse during the breeding season in Oregon. Final Report. Department of Fisheries and Wildlife, Oregon State University, Corvallis, Oregon.

Heath, B., R. Straw, S. Anderson, and J. Lawson. 1996. Proceedings of the Sage-grouse workshop. 6-7 September 1996, Pinedale, Wyoming.

Heath, B., R. Straw, S. Anderson, and J. Lawson. 1997. Sage-grouse productivity, survival, and seasonal habitat use near Farson, Wyoming. Wyoming Game and Fish Department, Completion Report. Cheyenne, Wyoming.

Sargeant, A. B., M. A. Sovada, and R. J. Greenwood. 1998. Interpreting evidence of depredation of duck nests in the prairie pothole region. U.S. Geological Survey, Northern Prairie Wildlife Research Center, Jamestown, North Dakota.

\section{Literature Cited}

Bowman, G. B., and L. D. Harris. 1980. Effect of spatial heterogeneity on ground-nest depredation. Journal of Wildlife Management 44: 806-813.

Connelly, J. W., and C. E. Braun. 1997. Long-term changes in Sage-grouse (Centrocercus urophasianus) populations in western North America. Wildlife Biology 3: 229-234.

Connelly, J. W., W. L. Wakkinen, A. D. Apa, and K. P. Reese. 1991. Sage-grouse use of nest sites in southeastern Idaho. Journal of Wildlife Management 55: 521-524.

Connelly, J. W., W. L. Wakkinen, A. D. Apa, K. P. Reese, and J. W. Fischer. 1993. Re-nesting by sage-grouse in southeastern Idaho. Condor 94: 1041-1043.

DeLong, A. K., J. A. Crawford, and D. C. DeLong, Jr. 1995. Relationships between vegetational structure and predation of artificial Sage-grouse nests. Journal of Wildlife Management 59: 88-92.

Furness, R. W. 1988. Predation on ground-nesting seabirds by island populations of red deer Cervus elaphus and sheep Ovis. Journal of the Zoological Society of London 216: 565-573.

Giesen, G. L., T. J. Schoenberg, and C. E. Braun. 1982. Methods for trapping Sage-grouse in Colorado. Wildlife Society Bulletin 10: 224-231.
Grasman, B. T., and E. C. Hellgren. 1993. Phosphorus nutrition in white-tailed deer: nutrient balance, physiological responses, and antler growth. Ecology 74: 2279-2296.

Gregg, M. A., J. A. Crawford, M. S. Drut, and A. K. DeLong. 1994. Vegetational cover and predation of Sagegrouse nests in Oregon. Journal of Wildlife Management 58: 162-166.

Johnson, M. K., and R. M. Hansen. 1979. Coyote food habits on the Idaho National Engineering Laboratory. Journal of Wildlife Management 43: 951-956.

Kucera, T. E., and R. H. Barrett. 1993. The Trailmastec camera system for detecting wildlife. Wildlife Society Bulletin 21: 505-508.

Patterson, R. L. 1952. The Sage-grouse of Wyoming. Sage Books Inc., Denver, Colorado.

Redmond, G. W., D. M. Keppie, and P. W. Herzog. 1982. Vegetative structure, concealment, and success at nests of two races of spruce grouse. Canadian Journal of Zoology 60: 670-675.

Reichel. 1991. Relationships among coyote food habits, prey populations, and habitat use. Northwest Science 65: 133137.

Sealy, S. G. 1994. Observed acts of egg destruction, egg removal, and predation on nests of passerine birds at Delta Marsh, Manitoba. Canadian Field-Naturalist 108: 41-51.

Sveum, C. M., J. A. Crawford, and W. D. Edge. 1998. Use and selection of brood-rearing habitat by sage grouse in south-central Washington. Great Basin Naturalist 58: 344351.

Ullrey, D. E. 1982. Nutrition and antler development in white-tailed deer. Pages 37-48 in Antler development in Cervidae. Edited by R. D. Brown. Caesar Kleberg Wildlife Research Institute, Kingsville, Texas.

Wakkinen, W. L. 1990. Nest site characteristics and springsummer movements of migratory Sage-grouse in southeastern Idaho. M. S. thesis, University of Idaho, Moscow, Idaho.

Received 5 March 2001

Accepted 15 July 2003 